\title{
Intensity of ecotoxicants' accumulation in internal organs and milk of dairy cows in the North-West of Transurals
}

\author{
S.N. Koshelev ${ }^{1, *}$, A.A. Bakharev ${ }^{2}$, and O.V. Romanova ${ }^{3}$ \\ ${ }^{1}$ FSBEI of HE "Kurgan State Agricultural Academy named after T.S. Maltsev”, Kurgan, Russia \\ ${ }^{2}$ FSBEI of HE SAU of Northern Trans-Urals, Tyumen, Russia \\ ${ }^{3}$ FSBEI of HE "South Ural State Agrarian University", Troitsk, Russia
}

\begin{abstract}
The work of the agrarian sector of the economy is impossible without deep awareness of the serious environmental situation threat of anthropogenic factors' influence due to the increasing intensification system of processes in animal husbandry. In addition to understanding the processes occurring in connection with the increase in anthropogenic load, real-time information about the real situation in the agroecosystem is necessary. Forecast of decision-making, consequences of certain actions. Control and monitoring of changes in the environmental situation. Therefore, the current control and the real system for assessing the ecological situation is important for the correct ecological activity of the agrarian organization. The greatest ecotoxicants' concentration is observed in the body of experimental animals, most of all in the respiratory and excretory organs. The minimum level of ecotoxicants was observed in muscle tissue, hence it is an environmentally friendly livestock product. The concentration of arsenic, mercury in the experiment is at the level of trace indicators. The level of ecotoxicants' accumulation in drinking cow's milk was established, the correlation between the pollutants' level in the product and the location of agricultural production, season and production time was found.
\end{abstract}

\section{Introduction}

Negative environmental factors influence homeostasis, health and the amount of milk received. Regular ingress of a seemingly small amount of pollutants with feed adversely affects health, productive longevity, the immune system, so the relevance of the influence issue of abiotic and biotic factors on animals, particularly cows, is a very relevant research topic $[1,12]$.

To date, because of the anthropogenic load increase on agroecosystems, the biosphere is increasing by pollutants. This issue is relevant in connection with the influence increase of industrial agglomerations on the environment. Pollutants are released in all areas where people live $[3,7,10]$. At about three, four kilometers in the troposphere, there are areas of

\footnotetext{
${ }^{*}$ Corresponding author: ksn-18@yandex.ru
} 
contaminated aerosols over industrial agglomerations. These pollutants accumulate on the surface, leading to worldwide pollution and environmental catastrophe [6,9].

Entrance of ecotoxicants, including in livestock products, can have negative effects for people and the biosphere in general and the pollutants' concentration in the body is negative affects the health of animals. Dairy cows eat plant feed and, consequently, can concentrate heavy metals in the body with plant origin feed obtained in contaminated areas. Absorbing metals, plants only increase the level of their content in vegetative organs. Consuming the products of the agro-industrial complex, the human increases the concentration of ecotoxicants $[4,8]$. Milking cows concentrate ecotoxicants in the body that fall from the soil in the form of minerals. Getting into the living organism, many of them accumulate and lead to a toxic effect on the milking herd.

Muscle tissues and various organs are used as human food and they can contain unhealthy substances. Therefore, the migration of various chemical elements in the biogeochemical province causes interest, as well as the influence of anthropogenic load and products of technogenesis. When studying the HM level in the studied samples, it is advisable to apply a method that allows studying many samples and obtain an average compared to others and standards on this data. Perhaps an increase in the HM concentration in livestock products is due to that cattle eat feed when the content of pollutants is maximum $[2,5,11]$. Often during the period of plants' harvesting, vegetative parts going into the diet in a certain phase of the year have the maximum HM level. The works of many scientists, for example, V.B. Ilyin (1991), show data that the HM amount varies depending on the period of the year. The concentration of $\mathrm{Pb}$ in meadow grass in autumn is greater from 30 and up to 100 times higher than in summer.

\section{Materials and Methods}

According to the studies, three models of technogenic sites were identified in the NorthWest of the Kurgan region, which were different in terms of technogenic load:

1 - technogenic territories receiving great pressure from nearby industrialized regions (Kataysky district);

2 - the land on which the river Techa flows, which has radionuclides because of the East-Urals radioactive trace (Dalmatovsky district)

3 - areas of the region relatively receiving no serious anthropogenic load (Shadrinsky, Kargapolsky districts)

The samples were investigated in the FSI SACS "Shadrinskaya" No POCC 00015102269 by arbitration methods. $\mathrm{Fe}, \mathrm{Cu}, \mathrm{Zn}, \mathrm{Mg}, \mathrm{Pb}, \mathrm{Cd}, \mathrm{As}, \mathrm{Hg}$ were analyzed in the internal organs of animals (GOST 30178-96) using atomic absorption (AAS) in Spectrophotometer Spectr No5 with ISO 8288 - 86.

\section{Results and Discussion}

Regular influence of various negative abiotic and biotic environmental factors on living organisms leads to a deterioration of health and resistance, and therefore dramatically reduce immunity, productive indicators of animals, reproducible qualities. Changes in the impact of anthropogenic factors towards increasing their effects have occurred relatively recently against the background of the evolutionary process of living organisms.

The results of our research will allow to perform monitoring the HM entry into a living organism and their transition into products and accumulation in organs and tissues of dairy cows. It is possible to analyze the pollutants' flow into the food chain and their impact on the population of farm animals. 
Quantitative data on the ecotoxicants' concentration in agricultural food products in the Kurgan region were not found. When studying the HM level in the studied samples, it is advisable to apply a method that allows studying many samples and obtain an average compared to others and standards on this data.

For study, the elementary composition of the organs by A.A.Kist (1987) was taken.

The HM level was studied in muscle tissue, internal organs. The data we have obtained in our studies are shown in Table 1. Different organs and tissues concentrate toxicants in different ways; hence their amount is higher in the living body than their level in the diet.

When studying the flesh, the cut was made in the back area in the longissimus muscle. Reverses the result of fewer pollutants in meat (table 1).

Table 1. Average heavy metals in the cows' muscles of agricultural enterprises North-West Kurgan region, $\mathrm{mg} / \mathrm{kg},(\overline{\mathrm{X}} \pm \mathrm{S} \overline{\mathrm{x}})$.

\begin{tabular}{|c|c|c|c|c|c|c|}
\hline Territory (district) & $\mathrm{Pb}$ & $\mathrm{Cd}$ & As & $\mathrm{Hq}$ & $\mathrm{Cu}$ & $\mathrm{Zn}$ \\
\hline 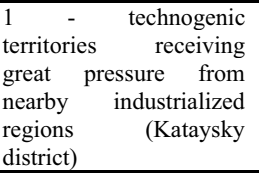 & $0.26 \pm 0.01$ & $0.019 \pm 0.003$ & $0.0025 \pm 0.002$ & $0.002 \pm 0.000$ & $1.37 \pm 0.72$ & $31.57 \pm 8.31$ \\
\hline from MPC & 0.5 & 0.38 & 0.02 & 0.07 & 0.27 & 0.45 \\
\hline $\begin{array}{l}2 \text { - the land on which the } \\
\text { river Techa flows, which } \\
\text { has radionuclides } \\
\text { because of the East- } \\
\text { Urals radioactive trace } \\
\text { (Dalmatovsky district) }\end{array}$ & $0.21 \pm 0.02$ & $0.016 \pm 0.01$ & $0.003 \pm 0.0001$ & $0.003 \pm 0.004$ & $1.46 \pm 0.68$ & $24.51 \pm 6.59$ \\
\hline from MPC & 0.4 & 0.31 & 0.03 & 0.1 & 0.29 & 0.35 \\
\hline $\begin{array}{l}33 \text { - areas of the region } \\
\text { relatively receiving no } \\
\text { serious anthropogenic } \\
\text { load, Shadrinsky district }\end{array}$ & $0.19 \pm 0.03$ & $0.017 \pm 0.001$ & $0.0015 \pm 0.003$ & $0.002 \pm 0.003$ & $1.55 \pm 0.3$ & $25.92 \pm 1.71$ \\
\hline from MPC & 0.4 & 0.33 & 0.01 & 0.07 & 0.31 & 0.37 \\
\hline $\begin{array}{lc}3 \text { - areas of the region } \\
\text { relatively } & \text { receiving no } \\
\text { serious } & \text { anthropogenic } \\
\text { load, } & \text { Kargapolsky } \\
\text { district } & \\
\end{array}$ & $0.20 \pm 0.02$ & $0.015 \pm 0.002$ & not detected & $0.002 \pm 0.001$ & $1.65 \pm 0.95$ & $28.73 \pm 5.23$ \\
\hline from MPC & 0.4 & 0.39 & & 0.07 & 0.33 & 0.40 \\
\hline $\begin{array}{l}\text { Elementary composition } \\
\text { (A.A. Kist) }\end{array}$ & 0.2 & 0.06 & 0.16 & 0.02 & 3.1 & 180 \\
\hline MPC & 0.5 & 0.05 & 0.1 & 0.03 & 5.0 & 70 \\
\hline
\end{tabular}

The level of lead content in the muscle tissue flesh varied in the limit of 0.4 or 0.5 MPC. The presence of $\mathrm{Cd}$ pollutant was reduced to a limit of 0.39 in the studied area No.1, the MPC is 0.31 in area 2 and decreased from 0.33 MPC and 0.29 ( 3 territories).

The concentration of As and Hg in the samples' flesh was at about one-hundredths per cent of the MPC in all areas of the material sampling for analysis. $\mathrm{Cu}$ appeared at -0.27 - 0.33 MPC level and was evenly distributed across a technogenic province. The ecotoxicants' presence in the liver of all territories exceeded the level of muscle tissue.

However, there was a noticeably high $\mathrm{Pb}$ amount in the liver of highly productive dairy animals reaching the level of $0.90-0.97$ MPC. A high amount of $\mathrm{Cd}$ accumulated in the liver, which level ranged from $0.6-0.8$ of maximum permissible concentrations.

Copper and zinc accumulated in the liver of the studied productive animals in approximate amount of 0.6 to $0.7 \mathrm{MPC}$. 
$\mathrm{Pb}$ is regularly found in biota in general. There is very little data on the impact on the biological environment, its role. However, the toxicity of lead and its various compounds is well-known.

According to our data in the experimental animals' heart muscles, it was possible to establish that the amount of $\mathrm{Pb}$ was $0.08-0.11$ maximum permissible concentrations.

$\mathrm{Cd}$ salts are very toxic, leading to fatty change in the heart muscle, cause carcinogenic effect. Cd is released from living organisms for a very long time.

The cadmium content in the heart muscle was at the level of $0.8-1.0$ maximum permissible concentration.

$\mathrm{Hg}$ causes great importance because it pollutes the ecosystem a lot. The mercury content in the heart muscle was from 0.05 to 0 , MPC.

Arsenic as a chemical element has carcinogenic properties. The arsenic level in the heart was $0.01-0.04 \mathrm{MPC}$.

$\mathrm{Cu}$ is known to be a very well researched essential trace element. Chemical analysis showed that the copper content in the heart of the studied animals was at the level of 0.7 0.86 maximum permissible concentrations.

Living organisms need zinc to maintain homeostasis and vital activity, increase the productivity of farm animals. The content of $\mathrm{Zn}$ in the heart of the studied animals of the technogenic province ranged from $0.3-0.4 \mathrm{MPC}$.

Kidneys are a natural biological filter in the body of lactating cows. Consequently, many researchers understand the relatively high concentration of ecotoxicants in them in examined animals of all territories. The $\mathrm{Pb}$ amount in the kidneys was in the amount of 0.8 MPC.

The Cd presence in the kidney varied - 1,2 - 1.5 MPC. There were also traces of arsenic from $0.08-0.09$ maximum permissible concentrations.

The amount of mercury in by-products was found in quantities of $0.01-0.015$ maximum permissible concentrations.

The $\mathrm{Cu}$ level in internal organs, for example kidneys, ranged from 0.8 to 0.9 maximum permissible concentrations.

$\mathrm{Zn}$ content in the studied kidneys was at $0.7-0.8 \mathrm{MPC}$.

It should be noted that the lungs and kidneys collect various pollutants in a large volume. The presence of lead in all studied areas varied between 1.1 and 1.3 permissible concentrations. Cadmium was contained in the internal organ at the level of 1.6 to 1.9 of the maximum permissible concentrations. After studying the animals' lungs, arsenic levels in all studied areas were found to be $0.03-0.05 \mathrm{MPC}$. The amount of mercury was determined in the range from 0.02 to 0.04 MPC. Copper was detected in trace concentrations in the amount of $0.8-0.96$ maximum permissible concentrations. Zinc content was observed in the range of $0.7-0.8 \mathrm{MPC}$.

Consequently, according to the results of our analyses, it was revealed that the HM accumulation in the muscle tissue flesh, muscle tissue of the heart, liver, kidneys of the population of experimental animals proceeded equally, not depending on the geographical location of the territory.

Most of the studied ecotoxicants are taken over by the lungs, then to a lesser extent kidneys. Liver and heart muscles follow next. Further - muscle tissue. Zn adsorption goes descending in the direction of the kidney, then lung tissue, liver, heart muscles and muscles.

The accumulation of lead in organs and tissues is in the following order: the highest content in the lungs, liver, concentration in the kidneys, muscle tissue and heart. Copper and cadmium accumulate differently. First the lungs are the first to accumulate, then the kidneys. Less HM is found in the heart and liver, muscle tissue is the last. 
A different reaction to the pollutants of internal animals' organs is of interest. For kidneys and pulmonary tissue, the range of $\mathrm{HM}$ accumulation represents the following chain, in terms of reduction: $\mathrm{Cd}-\mathrm{Pb}-\mathrm{Cu}-\mathrm{Zn}-\mathrm{As}-\mathrm{Hg}$.

The ecotoxicants' accumulation in the liver goes down the next chain: first lead, then cadmium, copper, zinc, arsenic, mercury. HM behave differently in the muscular tissue of the heart: first cadmium, sequentially copper, zinc. Mercury and arsenic are the last in the sequence. The accumulation of chemical elements in muscle tissue is in the following order: $\mathrm{Pb}, \mathrm{Zn}, \mathrm{Cd}, \mathrm{Cu}, \mathrm{As}, \mathrm{Hg}$.

Milk and products obtained after its processing are regularly on the table of many the population, so it is a very important food product containing biologically indispensable substances.

Milk processing products and drinking milk are significantly susceptible to contamination by ecotoxicants, so it is necessary to clearly monitor their content. There is a clear relationship between the ecological well-being of the residence areas, the composition of milk and the health condition of the population.

Consequently, it is necessary to organize an environmental monitoring system that considers the geographical and geological features of different territories. A greater amount of cow's milk produced is consumed by the population in the areas of its production. Thus, it is necessary to annually monitor the pollutants' level in cow's milk and its processing products, which will help both economic entities producing milk and processors to improve the quality of products.

The analyses showed that the number of priority pollutants did not exceed MPC levels. In the technogenic territory of the North-West region, the level of HM content had no reliable differences.

In the overwhelming number of analyses, the content of priority ecotoxicants did not go beyond the normative indicators. In dairy products produced in Kataysky district, the $\mathrm{Zn}$ level was $0.85 \mathrm{MPC}$, in 3 territories the quantity was 0.98 maximum permissible concentration, Kargapolsky and Dalmatovsky districts - 0.80 MPC. The Cu concentration in animal products of the technogenic province was at $0.4-0.6 \mathrm{MPC}$. The Cd content varied in the range of $0.8-0.3 \mathrm{MPC}$ in samples of Kataysky milk ( 1 territory), 2 territory and 3 territory. The accumulation of lead in drinking milk was within $0.5-0.8 \mathrm{MPC}$.

The amount of arsenic and mercury was within the norm equal to hundredth percent of the maximum permissible concentrations.

We have performed the research on cow's milk in winter, summer, autumn, spring, Table 2 . Thus, we can consider the quality of milk by seasons of the year.

Table 2. The level of ecotoxicants in drinking milk at different seasons, $\mathrm{mg} / \mathrm{kg},(\overline{\mathrm{X}} \pm \mathrm{S} \overline{\mathrm{x}})$.

\begin{tabular}{|l|c|c|c|c|c|c|}
\hline $\begin{array}{l}\text { Time of } \\
\text { year }\end{array}$ & $\mathrm{Pb}$ & $\mathrm{Cd}$ & $\mathrm{As}$ & $\mathrm{Hq}$ & $\mathrm{Cu}$ \\
\hline $\begin{array}{l}\text { Autumn } \\
\text { period }\end{array}$ & $0.05 \pm 0.01$ & $0.025 \pm 0.003$ & $0.0016 \pm 0.012$ & $0.0001 \pm 0.0005$ & $0.37 \pm 0.31$ & $4.15 \pm 0.47$ \\
\hline $\begin{array}{l}\text { from } \\
\text { MPC }\end{array}$ & 0.5 & 0.8 & 0.03 & 0.02 & 0.4 & 0.8 \\
\hline $\begin{array}{l}\text { Winter } \\
\text { period }\end{array}$ & $0.05 \pm 0.02$ & $0.01 \pm 0.02$ & traces & not identified & $0.49 \pm 0.22$ & $2.86 \pm 0.09$ \\
\hline $\begin{array}{l}\text { from } \\
\text { MPC }\end{array}$ & 0.5 & 0.3 & & & 0.5 & 0.6 \\
\hline $\begin{array}{l}\text { Spring } \\
\text { period }\end{array}$ & $0.06 \pm 0.03$ & $0.015 \pm 0.001$ & $0.003 \pm 0.004$ & traces & $0.41 \pm 0.05$ & $4.79 \pm 0.41$ \\
\hline
\end{tabular}




\begin{tabular}{|l|c|c|c|c|c|c|}
\hline $\begin{array}{l}\text { from } \\
\text { MPC }\end{array}$ & 0.6 & 0.5 & 0.06 & & 0.4 & 0.96 \\
\hline $\begin{array}{l}\text { Summer } \\
\text { period }\end{array}$ & $0.07 \pm 0.01$ & $0.03 \pm 0.001$ & $0.002 \pm 0.005$ & $0.0001 \pm 0.0003$ & $0.34 \pm 0.08$ & $4.56 \pm 0.31$ \\
\hline $\begin{array}{l}\text { from } \\
\text { MPC }\end{array}$ & 0.7 & 1.0 & 0.04 & 0.02 & 0.30 & 0.9 \\
\hline MPC & 0.1 & 0.03 & 0.05 & 0.005 & 1.0 & 5.0 \\
\hline
\end{tabular}

There was a decrease in the ecotoxicants' concentration in the direction of the seasons of the year starting in spring, then summer season, transition to autumn and winter.

An increase in $\mathrm{Cd}$ in the summer and autumn of the year was established. The amount of lead increased in the spring and summer period of the year. The concentration of zinc increases in spring, summer and in the autumn period. Analysis of copper levels in milk showed almost the same content throughout the year.

Thus, the HM level in cow milk changes throughout the year. Therefore, it is necessary to determine the chemical elements' concentration of dairy products during the year.

\section{Conclusion}

As a result of the obtained data analysis, the highest concentration of pollutants was observed in by-products, mostly lungs, kidneys. Fewer pollutants were found in the muscle tissue; thus, they are the most environmentally safe products for humans.

The amount of arsenic, mercury was determined at the level of hundredths and tenths of the maximum permissible concentrations.

The level of ecotoxicants' accumulation in drinking milk has been established, the ecotoxicants' correlation in drinking cow's milk from the geographical location of the commodity producer, season, and period time of receiving milk were identified.

\section{References}

1. M.N. Gonokhova, Modern directions of science development in animal husbandry and veterinary medicine, Materials of the international scientific and practical conference dedicated to the 60th anniversary of the Department of Production Technology and processing of livestock products and the 55th anniversary of the Department of Foreign Languages, 84-87 (2019)

2. E.K. Eskov, M.D. Eskova, Herald of Hunting Studies, 14(2),119-123 (2017)

3. L.P. Koryakina, A.I. Pavlova, Topical issues of morphological science and education, Proceedings of the regional scientific-practical conference within the framework of the IX national congress with international participation "Ecology and Human Health in the North", 59-64 (2019)

4. O.S. Chalaya, A.I. Chalyi, Animal Husbandry and Veterinary Medicine, 4, 3-7 (2019)

5. N.I. Marmuleva, L.A. Ovchinnikova, V.A. Ponurovsky, P.N. Sheronova, Role of agrarian science in sustainable development of rural areas, materials of the collection of the II All-Russian (national) scientific conference. Novosibirsk State Agrarian University, 295-298 (2017)

6. T.V. Konovalova, Modern Problems of Science and Education, 3, 618 (2015) 
7. L.P. Koryakina, N.N. Grigoryeva, A.I. Pavlova, S.P. Pavlova, K.V. Plemyashov, Veterinary and Feeding, 7, 25-28 (2020)

8. M.O. Shabanov, Z.T. Baeva, R.Kh. Gadzaonov, V.B. Tsugkieva, B.A. Dzagurov, Kh.E. Kesaev, T.N. Kokov, Bulletin of Gorsky State Agrarian University, 56 (4), 113 119 (2019)

9. N.V. Schiptsova, M.G. Terentieva, Bulletin of the Chuvash State Agrarian Academy, 2 (2), 51-55 (2017)

10. O. Romanova, A. Zamyatin, S. Koshelev, Ecological Agriculture and Sustainable Development, 241-250 (South Ural State University, 2019)

11. S. Koshelev, O. Ilyasov, O. Romanova, Ecological Agriculture and Sustainable Development, 299-307 (South Ural State University, 2019)

12. S.F. Sukhanova, E.I. Alekseeva, N.A. Lushnikov, T.L. Leshchuk, S.N. Koshelev, G.E. Uskov, N.A. Pozdnyakova, L.G. Dostovalova, The Turkish Online Journal of Design Art and Communication, 419 (2018) 